\title{
РАЗВИТИЕ ЗАКОНА «О ЗЕМЛЕУСТРОЙСТВЕ» НА СОВРЕМЕННОМ ЭТАПЕ
}

\section{Кристина Александровна Терентьева}

Сибирский государственный университет геосистем и технологий, 630108, Россия, г. Новосибирск, ул. Плахотного, 10, обучающийся, тел. (999)446-74-35, e-mail: hexejenkins@bk.ru

Представлены результаты сравнительного анализа действующего закона «О землеустройстве» №78-Ф3 от 18.06.2001 и Проекта федерального закона «О землеустройстве» по состоянию на 28.01.2019. В статье рассматриваются предлагаемые в Проекте определения основных понятий, акцентируется внимание на изменении формулировки цели землеустройства, перечня землеустроительных мероприятий и землеустроительной документации. Обсуждается ограничение сферы действия закона категориями земель сельскохозяйственного назначения и лесного фонда. Предлагается расширение области действия закона на все категории земель кроме земель промышленности и населенных пунктов.

Ключевые слова: землеустройство, землеустроительные мероприятия, землеустроительная документация, категории земель

\section{DEVELOPMENT OF THE LAW "ON LAND MANAGEMENT" AT THE PRESENT STAGE}

\section{Kristina A. Terentyeva}

Siberian State University of Geosystems and Technologies, 10, Plakhotnogo St., Novosibirsk, 630108, Russia, Student, phone: (999)446-74-35, e-mail: hexejenkins@bk.ru

The results of a comparative analysis of the current law «on land management» № 78-FL of 18.06.2001 and the Draft Federal law «on land management» as of 28.01.2019 are presented. The article discusses the definitions of the main concepts proposed in the Draft, focuses on changing the wording of the purpose of land management, the list of land management measures and land management documentation. Limiting the scope of the law to categories of agricultural land and forest resources is discussed. It is proposed to extend the scope of the law to all categories of land except for industrial and residential areas.

Keywords: land management, land management measures, land management documentation, land categories

\section{Введение}

Земля - невоспроизводимое средство производства, ограниченное и неоднородное по качеству своих участков. Земли, находящиеся в границах территории Российской Федерации, составляют земельный фонд нашей страны. В статье 7 «Земельного кодекса» перечислены основные категории земель, каждая из которых имеет особые параметры, свойственные только ей: код, назначение и разрешенные виды использования.

Актуальность исследования обусловлена тем, что государство с помощью законодательства осуществляет охрану ценного природного ресурса. Если нерационально использовать земли нашей страны и ее природные ресурсы, то можно 
причинить непоправимый ущерб. На сегодняшний день в сфере землеустройства существует множество проблем национального масштаба: опустынивание и эрозия почв, осушение и загрязнение водных ресурсов, обезлесение.

С течением времени и развитием прогресса землеустройство претерпевало изменения от простейших операций до сложных систем мероприятий.

Целью исследований являлось рассмотрение изменений закона «О землеустройстве» по истечении почти двух десятилетий со времени его принятия.

В исследовании применялся сравнительно-аналитический метод изучения литературной и нормативно-правовой документации.

\section{Обсуждение}

Из-за необходимости, сложности и многообразия видов мероприятий, важно понимать само понятие землеустройства.

24 мая 2001 года Государственной думой был одобрен Федеральный закон «О землеустройстве» № 78-ФЗ и принят Советом Федерации 6 июня 2001 года. В этом федеральном законе даются толкования основным понятиям, объясняются принципы правового регулирования отношений при проведении землеустройства, основания и само проведение землеустройства, а также перечисляется землеустроительная документация.

Под землеустройством понимались мероприятия по изучению состояния земель, планированию и организации рационального использования земель и их охраны, образованию новых и упорядочению существующих объектов землеустройства и установлению их границы на местности (территориальное землеустройство), организации рационального использования гражданами и юридическими лицами земельных участков для осуществления сельскохозяйственного производства, а также по организации территорий, используемых общинами коренных малочисленных народов Севера, Сибири и Дальнего Востока Российской Федерации и лицами, относящимися к коренным малочисленным народам Севера, Сибири и Дальнего Востока Российской Федерации, для обеспечения их традиционного образа жизни (внутрихозяйственное землеустройство) [1].

На основе изменений, внесенных Федеральным законом от 13.05.2008 № 66Ф3, в определении больше не рассматривается образование новых и упорядочение существующих объектов землеустройства и установление их границ на местности (территориальное землеустройство). Вместо этого вносится описание местоположения и (или) установление на местности границ объектов землеустройства [2].

С момента внесения правок от 13.05.2008 № 66-Ф3 по настоящее время, в определение землеустройства не вносилось никаких изменений, пока в начале 2019 года минэкономразвития представило новый проект закона о землеустройстве, который на данный момент находится на доработке.

Рассмотрим и проанализируем изменения, которые предлагается внести в сферу землеустройства нашей страны.

Во-первых, проект закона внес изменения в понятие «землеустройство». 
Согласно ГОСТу 26640-85 термин «Рациональное использование земель», на который опирается действующий федеральный закон и действует в отношении всех категорий земель, означает обеспечение всеми землепользователями в процессе производства максимального эффекта в осуществлении целей землепользования с учетом охраны земель и оптимального взаимодействия с природными факторами [3].

В проекте закона прописана своя трактовка термина «надлежащее (рациональное) использование земель». Несмотря на то, что в определении «землеустройства» термин применяется только в отношении земель, расположенных в территориальной зоне сельскохозяйственного назначения, часть 5 статьи 1 проекта закона рассматривает использование земель в сельском и лесном хозяйстве [4].

Определение подразумевает сохранение плодородия и иных природных свойств почв земельных участков, позволяющих использовать земельные участки для ведения сельского и лесного хозяйства. Нацеленность на извлечение максимального эффекта в процессе эксплуатации земли не предусматривается. Иначе говоря, земли необходимо использовать в соответствии с их целевым назначением способами, которые не должны наносить вред окружающей среде.

Землеустроительные мероприятия в проекте закона не применяются в отношении земель, предназначенных для застройки, нужд обороны и безопасности государства.

Нынешнем законодательством не определены цели, и задачи землеустройства, которые предусматривает проект закона. Так, например, ушедшие из определения «землеустройства» меры по организации территорий для обеспечения традиционного образа жизни коренных малочисленных народов Севера, Сибири и Дальнего Востока Российской Федерации теперь являются целью.

Различия в землеустроительной документации представлены в таблице.

Стоит также отметить, что согласно проекту закона, в случае его принятия и вступления в силу, землеустроительные документы в виде проекта внутрихозяйственного, межхозяйственного землеустройства, схемы землеустройства муниципального образования и схемы охраны земель будут признаны недействующими, если были приняты до 1 января 1997 года.

Также Проект закона определяет понятие «землеустроитель»:

1. Землеустроитель - лицо, осуществляющее землеустроительные мероприятия и работы в соответствии с настоящим Федеральным законом (часть 10 статья 1);

2. Землеустроителем является федеральное государственное бюджетное учреждение, подведомственное федеральному органу исполнительной власти, уполномоченному Правительством Российской Федерации на осуществление государственной регистрации прав на недвижимое имущество, государственного кадастрового учета и предоставление сведений Единого государственного реестра недвижимости (часть 1 статья 44). 
Сравнительный анализ землеустроительной документации

в законе «О землеустройстве» №78-ФЗ от 18.06.2001

и Проекте Федерального закона «О землеустройстве» от 28.01.2019

\begin{tabular}{|c|c|}
\hline №78- Ф3 & $\begin{array}{c}\text { Проект Федерального закона } \\
\text { «О землеустройстве» }\end{array}$ \\
\hline $\begin{array}{l}\text { - генеральная схема земле- } \\
\text { устройства территории Российской } \\
\text { Федерации, схема землеустройства } \\
\text { территорий субъектов РФ, схема зем- } \\
\text { леустройства муниципальных образо- } \\
\text { ваний, схемы использования и охраны } \\
\text { земель; } \\
\text { - карты (планы) объектов земле- } \\
\text { устройства; } \\
\text { - проекты внутрихозяйственного } \\
\text { использования; } \\
\text { - проекты улучшения сельскохо- } \\
\text { зяйственных угодий, освоения новых } \\
\text { земель, рекультивации нарушенных } \\
\text { земель, защиты земель от эрозии, се- } \\
\text { лей, подтопления, заболачивания, вто- } \\
\text { ричного засоления, иссушения, уплот- } \\
\text { нения и загрязнения отходами произ- } \\
\text { водства и потребления, радиоактив- } \\
\text { ными и химическими веществами, за- } \\
\text { ражения и других негативных воздей- } \\
\text { ствий; } \\
\text { - материалы почвенных, геобота- } \\
\text { нических и других обследований и изыс- } \\
\text { каний, оценки качества земель, инвента- } \\
\text { ризации земель; } \\
\text { - тематические карты и атласы } \\
\text { состояния и использования земель; }\end{array}$ & $\begin{array}{l}\text { - сельскохозяйственный регла- } \\
\text { мент; } \\
\text { - землеустроительная карта (мо- } \\
\text { жет являться частью другого земле- } \\
\text { устроительного документа); } \\
\text { - проект землеустройства; } \\
\text { - соглашение о проведении зем- } \\
\text { леустройства; } \\
\text { - материалы землеустроитель- } \\
\text { ных изысканий; } \\
\text { - отчет об авторском надзоре за } \\
\text { исполнением объекта землеустрой- } \\
\text { ства; } \\
\text { - описание административных } \\
\text { границ. }\end{array}$ \\
\hline
\end{tabular}

К землеустроительным мероприятиям проект федерального закона относит:

1. изучение состояния земель;

Данное мероприятие может выполняться:

1) лицом, являющимся индивидуальным предпринимателем и имеющим высшее образование по направлению подготовки «землеустройство и кадастры» или «почвоведение»;

2) юридическими лицами, работники которых имеют образование по направлению подготовки «землеустройство и кадастры» или «почвоведение»; 
2. планирование использования и охраны земель;

3. подготовка сельскохозяйственного регламента;

4. подготовка и выполнение проекта землеустройства;

5. авторский надзор за выполнением проекта землеустройства;

6. подготовка описания административных границ.

Данные мероприятия могут выполняться лицами, являющимися работниками федерального государственного бюджетного учреждения, подведомственного федеральному органу исполнительной власти, уполномоченному Правительством Российской Федерации на осуществление государственной регистрации прав на недвижимое имущество, государственного кадастрового учета и предоставление сведений Единого государственного реестра недвижимости, имеющими высшее образование по направлению подготовки «землеустройство и кадастры». Также мероприятия могут выполняться кадастровым инженером.

Подведя итог, хочется отметить, что проект закона по-своему трактует понятие землеустройства, раскрывает понятие и содержание землеустроительных мероприятий, определяет цели и задачи землеустройства, устанавливает требования к лицам, признаваемых землеустроителями, однако проект закона не предусматривает цели рационального использования земель, а заменяет его надлежащим использованием. Количество землеустроительной документации сокращено, что упрощает способы и методы управления земельными ресурсами. Проект закона ограничивает землеустройство в рамках категории земель сельхозназначения, и не затрагивает земли других категорий, организация использования которых тоже должна быть защищена землеустроительными и правовыми нормами.

\section{БИБЛИОГРАФИЧЕСКИЙ СПИСОК}

1. Федеральный закон от 18 июня 2001 г. № 78-ФЗ «О землеустройстве» (с изменениями и дополнениями от 03 августа 2018 г.).

2. Федеральный закон от 18 июня 2001 г. № 78-Ф3 «О землеустройстве» (с изменениями и дополнениями от 13 июля 2008 г.).

3. ГОСТ 26640-85. Земли. Термины и определения [Электронный ресурс] : межгос. стандарт - Введ. 01.01.1987. - Режим доступа: http://docs.cntd.ru/document/1200023264 - Загл. с экрана.

4. О землеустройстве [Электронный ресурс] : проект федерального закона Министерства экономического развития Российской Федерации № 02/04/01-19/00087994. - Доступ из справ.правовой системы «КонсультантПлюс».

5. Хлыстун, В.Н., Семочкин, В.Н., Папаскири, Т.В. О принципах и содержании проекта нового закона «О землеустройстве» // Журнал «Экономика сельскохозяйственных и перерабатывающих предприятий». - 2019. - №9. - С. 52-56.

(C) К. А. Терентьева, 2021 